\title{
RADIOCARBON AND URANIUM-SERIES DATING OF THE PLITVICE LAKES TRAVERTINES
}

\author{
DUŠAN SRDOČ, ${ }^{1,3} \mathrm{~J} . \mathrm{K}$. OSMOND, ${ }^{2}$ NADA HORVATINČIĆ, ${ }^{3}$ ADEL A. DABOUS ${ }^{4}$ and \\ BOGOMIL OBELIĆ ${ }^{3}$
}

\begin{abstract}
Radiocarbon and uranium-series ages of the calcareous deposits of the Plitvice Lakes show that travertines were deposited during three warm, humid, interglacial oxygen isotope stages. According to our measurements, only calcite crystals or crystal aggregates represent reliable material for both ${ }^{230} \mathrm{Th} /{ }^{234} \mathrm{U}$ and ${ }^{234} \mathrm{U} /{ }^{238} \mathrm{U}$ dating. Compact old travertine in the form of sandstone is less reliable; it can be dated by both methods provided that its detrital contamination is not significant, demonstrated by very low ${ }^{14} \mathrm{C}$ activity $(<1.5-2.0 \mathrm{pMC})$ and a high ${ }^{230} \mathrm{Th} /{ }^{232} \mathrm{Th}$ ratio. Old porous travertine contaminated with recent carbonates and $\mathrm{Th}$-bearing clay $\left(\mathrm{pMC}>5,{ }^{230} \mathrm{Th} /{ }^{232} \mathrm{Th}<5\right)$ gives erroneous results by both methods. Stage 1 (Holocene) deposition is shown primarily by ${ }^{14} \mathrm{C}$ dating corroborated by sedimentological and palynologic studies as well as by both ${ }^{230} \mathrm{Th} /{ }^{234} \mathrm{U}$ and ${ }^{234} \mathrm{U} /{ }^{238} \mathrm{U}$ disequilibrium methods. The intensive growth of travertine barriers coincided with significant climate warming in the Holocene. Stage 5 deposition is confirmed by the ${ }^{230} \mathrm{Th} /{ }^{234} \mathrm{U}$ dating of crystalline calcite aggregates embedded in the travertine matrix and by concordant ${ }^{230} \mathrm{Th} /{ }^{234} \mathrm{U}$ and ${ }^{234} \mathrm{U} /{ }^{238} \mathrm{U}$ ages, assuming that the ${ }^{234} \mathrm{U} /{ }^{238} \mathrm{U}$ activity ratio of 1.88 observed in modern streams and in Holocene deposits can be extended to past epochs. The travertine deposition period was very short, peaking $c a .120 \pm 10 \mathrm{ka} \mathrm{BP}$. Stage 11 deposition is indicated by ${ }^{234} \mathrm{U} /{ }^{238} \mathrm{U}$ dating only, the period being within the ${ }^{234} \mathrm{U}$ decay range, but not that of ${ }^{230} \mathrm{Th}$. Stage 11 travertine was deposited ca. $420 \pm 50 \mathrm{ka} \mathrm{BP}$. We did not find travertine samples with U-series ages indicating a growth period during relatively warm Stages 7 and 9; due to the scarcity of old travertine outcrops, these and possibly other stages cannot be excluded on the basis of presented data. All of these isotopic dating results concur with the field relation of the travertine complex of the Plitvice Lakes.
\end{abstract}

\section{INTRODUCTION}

The Plitvice Lakes are a spectacular series of travertine dams, lakes and waterfalls located in the karst region of northwestern Dinarides in central Croatia (Fig. 1). According to Polšak (1979a,b), the area owes its abundant karst phenomena to the thick carbonate section of the Upper Triassic to the Cretaceous. The impermeable Upper Triassic and Lower Jurassic dolomites and marly limestones prevent vertical water circulation. The permeable regions are characterized by karst dolinas, swallow holes, caves and poljes, whereas springs are scarce. Travertines are deposited on either limestone or dolomite bedrock.

The tectonics of this area is dominated by faulting. A prominent, longitudinal, NW-SE striking fault separates the Senonian rudistic limestones from the Triassic rocks to the southwest. The transverse fault between Lakes Kozjak and Prošće controls the locations of a series of small lakes. During the Mesozoic, an environment prevailed, favorable for carbonate platform deposition within a tectonically quiescent regime. This situation terminated at the end of the Eocene when the Dinaric Mountains folded.

Travertine forms waterfalls, barriers and subaqueous fine-grained lake-fill accumulations throughout the Plitvice National Park. Barrier deposits form dams intercepting the free flow of water. Travertines are always associated with biota, predominantly microscopic algae and cyanobacteria, abundant moss growth and higher plant taxa (Golubić 1973; Chafetz and Folk 1984; Marčenko et al. 1989). Travertine begins to form with deposits of calcite microcrystals on the periphyton. Relatively rapid ramification follows, resulting in a fragile, spongy structure consisting of a large amount of

${ }^{1}$ Brookhaven National Laboratory, S\&EP, Bldg. 535A, P.O. Box 5000, Upton, New York, 11973-5000 USA

${ }^{2}$ Department of Geology, Florida State University, Tallahassee, Florida 32306 USA

${ }^{3}$ Rudjer Bošković Institute, P.O.B. 1016, Bijenicka 41001 Zagreb, Croatia

${ }^{4}$ Geology Department, Ain Shams University, Cairo, Egypt 


\section{PLITVICE NATIONAL PARK}



Fig. 1. Map of the Plitvice Lakes travertine deposition areas discussed in this study. A, B, C= sampling sites of old travertines; Holocene samples were collected throughout the entire area, mostly along the streams. $\downarrow$ = surface water sampling sites; $\oplus=$ lake sediment and peat coring sites; $*$ = sampled old travertine outcrop; $-=$ surface water sampling sites for U-series dating; $O=$ spring. Insets show geomorphic positions of (A) the Smolxića Pecina travertine and cave deposits and (B) Gradina old travertine. A. 1. Travertine and speleothems; 2. Korana River. B. 1. Old travertine outcrop; 2. Lake Gradinsko; 3. Lake Kozjak. C. Old travertine deposits near Plitvički Ljeskovac village. 
organic matter in a calcite matrix, often called tufa. Further solidification into a typical travertine texture takes several thousand years and is characterized by loss of the organic components via microbial decomposition, and recrystallization of calcite to form a more compact and solid structure. According to Chafetz, Srdoč and Horvatinčić (1990), the Plitvice travertines are composed of very fine-to-medium crystalline, equant to bladed, low-magnesian spar. The internal truncation surfaces suggest alternating periods of erosion and precipitation of older spar crust. Petrographic analyses show that cyanobacteria, fungi and other microbial organisms bore into the spar and micrify it. This pervasive diagenetic process occurs throughout the waterfall and barrier deposits in this environment (Chafetz, Srdoč and Horvatinčić 1994).

In this paper, we discuss travertine samples ${ }^{14} \mathrm{C}$-dated at the Rudjer Boškovic Institute and U-seriesdated at Florida State University. We credit other laboratories by indicating their code numbers in comparisons with our results. Tables 1-5 summarize the results of this study.

\section{SAMPLING}

Srdoc and co-workers collected samples of various forms of travertine in the Plitvice National Park, primarily for ${ }^{14} \mathrm{C}$ dating. Samples Z-396, -398 and -940 , from the same travertine outcrop near Plitvicki Ljeskovac, were sent for cross-checking to various laboratories as indicated in Table 3.

A systematic search for relict travertine outcrops within the Park revealed old-appearing deposits resembling the present active barriers at three locations: Korana River Canyon; Gradina; and Plitvički Ljeskovac (Fig. 1). Outcrops of old travertine are very rare when compared with ubiquitous recent travertine deposited along the streams and lakes shown in Figure 1. A location abundant in old travertine occurs on the rim of the Korana River Canyon (Fig. 1A). The contour lines suggest an extinct travertine-depositing stream emptying into the Korana River. The location features a cave, Smolčća Pećina, and a travertine block protruding through the cave ceiling. On a hill overlooking Lake Kozjak, named Gradina (Fig. 1B), we found a single outcrop of old travertine. Its present position bears no relation to any travertine-depositing water body; the closest stream or lake is $35 \mathrm{~m}$ below the outcrop. This travertine block consists of porous calcite concretions resembling petrified aquatic moss and more compact sections without any distinct morphology. At the confluence of the Bijela Rijeka and Crna Rijeka creeks, in an area ca. $3 \mathrm{~km}$ long and $0.5 \mathrm{~km}$ wide, dry travertine barriers and huge scattered travertine blocks abound. We refer to this confluence area as Ljeskovac, after Plitvički Ljeskovac, a nearby village (Fig. 1C).

TABLE 1. Uranium Concentration and Activity Ratio of the Plitvice National Park Water Samples*

\begin{tabular}{|c|c|c|c|}
\hline $\begin{array}{c}\mathrm{FSU}^{\dagger} \\
\text { sample no. }\end{array}$ & Location & $\begin{array}{l}\text { U concentration } \\
\left(\mu \mathrm{g} \mathrm{liter}^{-1}\right)\end{array}$ & $\begin{array}{l}{ }^{234} \mathrm{U} /{ }^{238} \mathrm{U} \\
\text { activity ratio }\end{array}$ \\
\hline YK-18 & $\begin{array}{l}\text { Bijela Rijeka, } \\
\text { headwater spring }\end{array}$ & $0.24 \pm 0.04$ & $1.91 \pm 0.06$ \\
\hline YGW-711 & Matica, inflow & $0.36 \pm 0.03$ & $1.85 \pm 0.05$ \\
\hline YGW-712 & $\begin{array}{l}\text { Kozjak Mostovi, } \\
\text { outflow }\end{array}$ & $0.33 \pm 0.02$ & $1.89 \pm 0.04$ \\
\hline
\end{tabular}

\footnotetext{
"See Figure 1 for sampling locations

${ }^{\dagger} \mathrm{FSU}=$ Florida State University
} 
The dense forest covering the park made a systematic search of old outcrops rather difficult. Also, erosion of old travertine during cold periods and recent alluvial deposits prevented a more thorough sampling, which could have revealed more travertine growth periods than described here. Drilling travertine barriers is not permitted in the national park; however, natural dislocations, crumbling and erosion of barriers exposed the entire profile of many travertine deposits, enabling us to collect a representative number of samples throughout the investigated area. When it became obvious that clean crystalline calcite aggregates were more reliable for ${ }^{230} \mathrm{Th} /{ }^{234} \mathrm{U}$ dating, we intensified our search for such samples, also preserving the adjacent porous travertine for analyses of paired samples. Whereas young travertines were fairly randomly sampled, we sampled old travertine rather systematically for clean calcite crystals. Consequently, the number of old travertine samples (Fig. 2A) far exceeds their actual abundance.

We also collected three 25-liter water samples (YGW-711, YGW-712, YK18) (Fig. 1), evaporated them to dryness and analyzed the residue for $U$ concentration and for ${ }^{234} U /{ }^{238} U$ activity.

\section{RADIOCARBON DATING HOLOCENE TRAVERTINES}

\section{Biogenic Carbon in Travertine}

${ }^{14} \mathrm{C}$ dating of travertine (calcareous tufa) is based on the fact that a large proportion of its carbon is of biogenic origin (Srdoc et al. 1980). Theoretically, travertines should contain 50\% biogenically originated carbon. However, in contrast to stoichiometric expectations, the measurements of initial ${ }^{14} \mathrm{C}$ activity of travertine-depositing stream water dissolved inorganic carbon (DIC) and freshly deposited tufa gave significantly higher ${ }^{14} \mathrm{C}$ activity, ranging from 60 to $90 \%$ of the modern standard. The excess ${ }^{14} \mathrm{C}$ is of biogenic or atmospheric origin, introduced into the groundwater via isotopic exchange between DIC and gaseous $\mathrm{CO}_{2}$ during seeping and percolation (Mook 1976, 1980;

TABLE 2. Holocene Travertines of the Plitvice National Park* ${ }^{14} \mathrm{C}$ and U-Series Dating

\begin{tabular}{|c|c|c|c|c|c|c|c|}
\hline $\begin{array}{l}\text { Z-no. } \\
\text { Lab no. }\end{array}$ & $\begin{array}{c}\mathrm{U} \\
(\mathrm{ppm})\end{array}$ & $\frac{{ }^{234} \mathrm{U}}{{ }^{238} \mathrm{U}}$ & $\begin{array}{c}{ }^{234} \mathrm{U} \\
\text { age }(\mathrm{ka})\end{array}$ & $\frac{{ }^{230} \mathrm{Th}}{{ }^{234} \mathrm{U}}$ & $\frac{{ }^{230} \mathrm{Th}}{{ }^{232} \mathrm{Th}}$ & $\begin{array}{c}{ }^{230} \mathrm{Th} \\
{ }^{234} \mathrm{U} \\
\text { age (ka) }\end{array}$ & $\begin{array}{l}{ }^{14} \mathrm{C} \text { pMC } \\
\text { age }^{\dagger}(\mathrm{ka})\end{array}$ \\
\hline $\begin{array}{l}\text { Z-1176 } \\
\text { USGS: } \\
\text { ZAG-4 }\end{array}$ & $\begin{array}{r}0.38 \\
\pm 0.01\end{array}$ & $\begin{array}{r}1.79 \\
\pm 0.03\end{array}$ & $38 \pm 13$ & $\begin{array}{r}0.013 \\
\pm 0.005\end{array}$ & -- & $1.4 \pm 0.6$ & 73.2 \\
\hline $\begin{array}{l}\text { Z-941 } \\
\text { NLfB: } \\
\text { Uh-144 }\end{array}$ & $\begin{array}{r}0.24 \\
\pm 0.01\end{array}$ & $\begin{array}{r}1.85 \\
\pm 0.03\end{array}$ & $12 \pm 13$ & $\begin{array}{r}0.004 \\
\pm 0.021\end{array}$ & 21 & $0.4 \pm 1.9$ & $\begin{array}{l}\text { Modern samples pre- } \\
\text { nuclear bomb tests: } \\
\text { growing period: } \\
\sim \text { AD } 1800-1900\end{array}$ \\
\hline $\begin{array}{l}\text { Z-2146 } \\
\text { FSU: } \\
62(I)\end{array}$ & $\begin{array}{r}0.37 \\
\pm 0.04\end{array}$ & $\begin{array}{r}1.78 \\
\pm 0.07\end{array}$ & $43 \pm 33$ & -- & -- & -- & \\
\hline $\begin{array}{l}\text { Z-1114 } \\
\text { FSU: } \\
1 A(I)\end{array}$ & $\begin{array}{r}0.38 \\
\pm 0.04\end{array}$ & $\begin{array}{r}1.87 \\
\pm 0.06\end{array}$ & $4 \pm 25$ & $\begin{array}{r}0.05 \\
\pm 0.04\end{array}$ & 33 & $3.1 \pm 2.5$ & $\begin{array}{l}59.8 \\
1670 \pm 100\end{array}$ \\
\hline $\begin{array}{l}\text { Z-1114 } \\
\text { FSU: } \\
1 B(0)\end{array}$ & $\begin{array}{r}0.31 \\
\pm 0.02\end{array}$ & $\begin{array}{r}1.83 \\
\pm 0.06\end{array}$ & $21 \pm 26$ & $\begin{array}{r}0.05 \\
\pm 0.03\end{array}$ & 46 & $3.1 \pm 1.8$ & \\
\hline
\end{tabular}

"Samples were speleothems from travertine caves

'Initial ${ }^{14} \mathrm{C}$ activity $=74 \mathrm{pMC}$ 


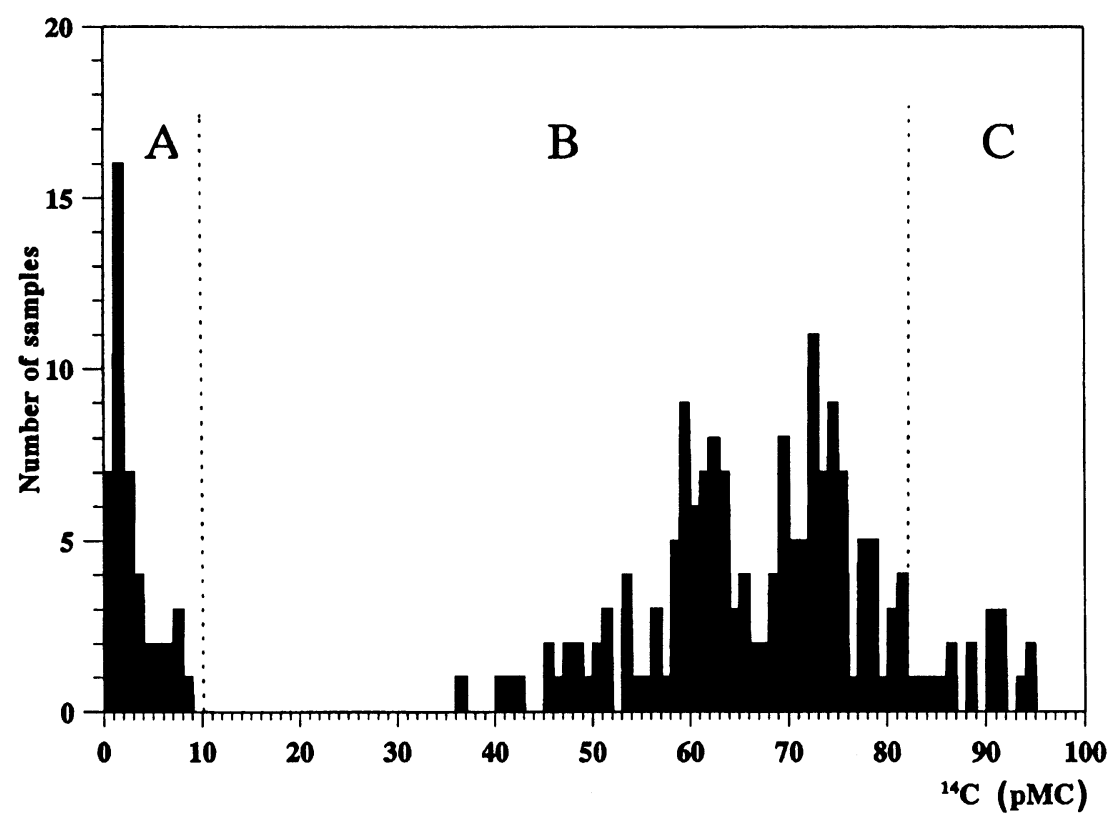

Fig. 2A. Number of samples collected in the Plitvice National Park $v s .{ }^{14} \mathrm{C}$ activity expressed as pMC. A. Old travertine outcrops sampled systematically; we regarded their ${ }^{14} \mathrm{C}$ content as contamination. B. Holocene samples collected randomly; C. Recent travertines deposited from surface water contaminated with bomb-test-produced ${ }^{14} \mathrm{C}$.

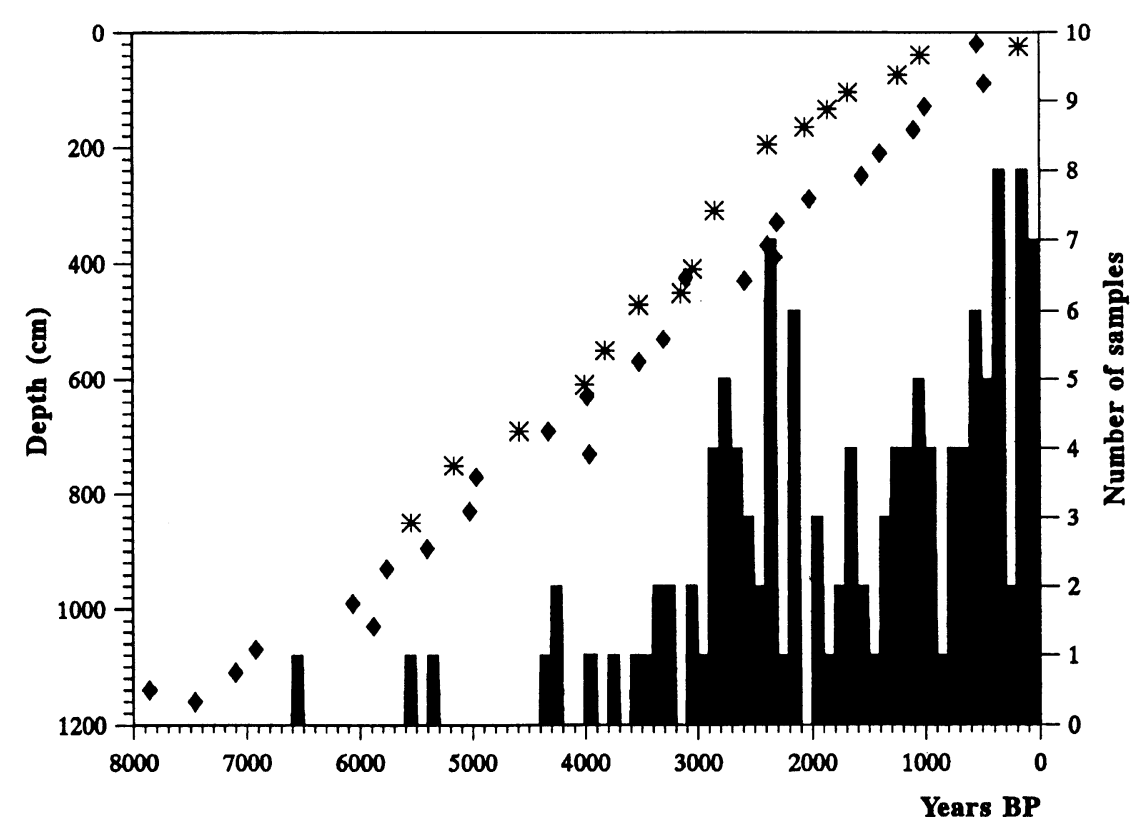

Fig. 2B. Number of randomly collected Holocene travertine samples (right) $v s .{ }^{14} \mathrm{C}$ age. ${ }^{14} \mathrm{C}$ age of travertine is calculated by applying the initial ${ }^{14} \mathrm{C}$ activity at sampling location, which ranged from $\sim 70$ to 83 pMC. Core depth (left): $*$ = peat; $\diamond=$ Lake Prošće sediment. Coring sites are shown in Fig. 1. 
Krajcar Bronić et al. 1986). Redistribution of ${ }^{14} \mathrm{C}$ during travertine formation has been observed in young, growing travertine structures in the Plitvice National Park. Srdoč et al. (1980) showed that ${ }^{14} \mathrm{C}$ is evenly distributed in huge travertine aggregations due to the percolation of stream water throughout the porous structure during formation. The ${ }^{14} \mathrm{C}$ clock is set when the whole structure

TABLE 3. Inactive (Dry) Travertine Barriers of the Plitvice National Park, Plitvicki Ljeskovac U-Series Dating

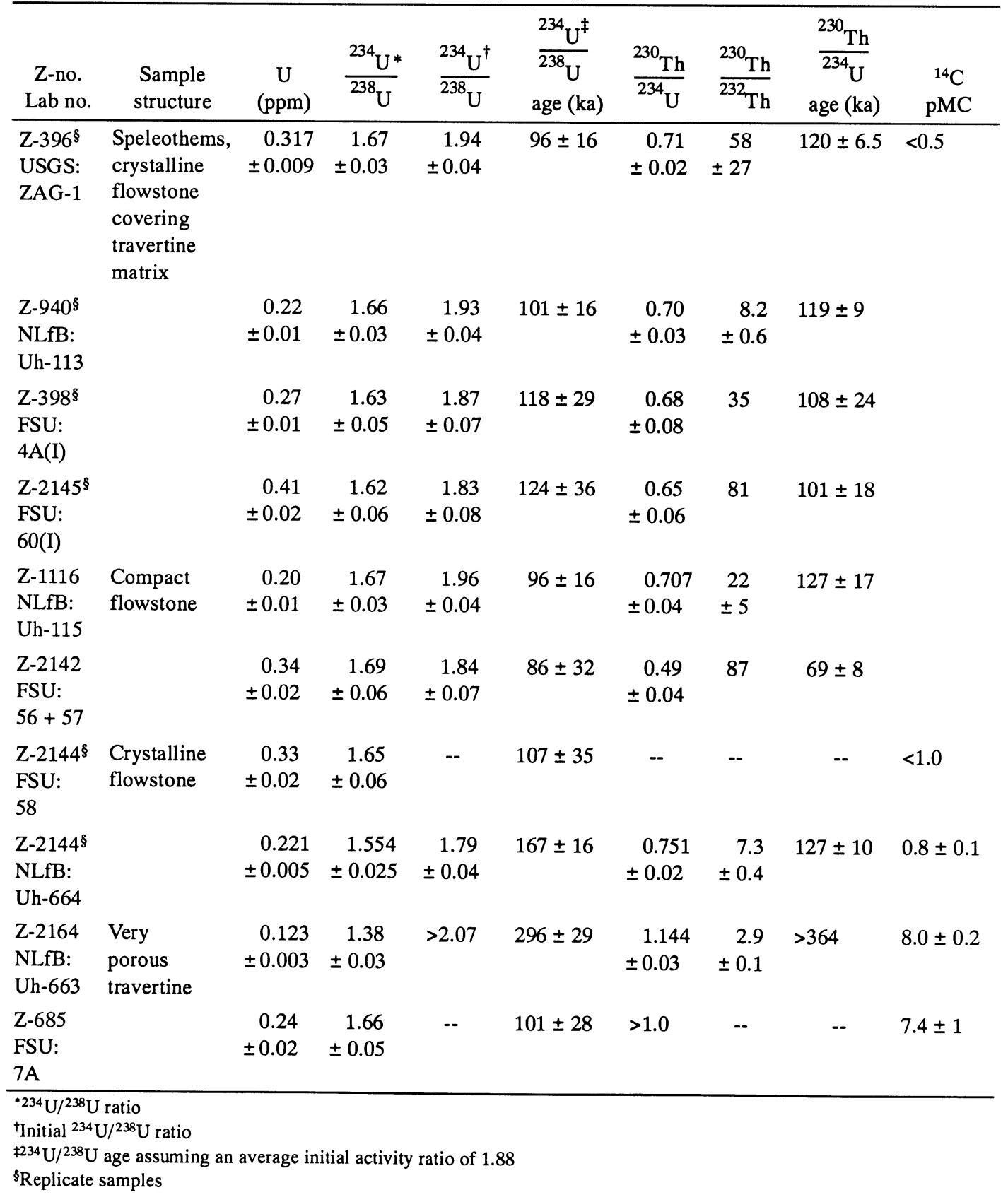


TABLE 4. Travertines of the Plitvice National Park, Gradina U-Series Dating

\begin{tabular}{|c|c|c|c|c|c|c|c|c|c|}
\hline $\begin{array}{l}\text { Z-no. } \\
\text { Lab. } \\
\text { no. }\end{array}$ & $\begin{array}{l}\text { Sample } \\
\text { Structure }\end{array}$ & $\underset{(\mathrm{ppm})}{\mathrm{U}}$ & $\frac{{ }^{234} U^{*}}{{ }^{238} U}$ & $\frac{{ }^{234} U^{\dagger}}{{ }^{238} U}$ & $\begin{array}{l}\frac{{ }^{234} U^{\ddagger}}{{ }^{238} U} \\
\text { age (ka) }\end{array}$ & $\frac{{ }^{230} \mathrm{Th}}{{ }^{234} \mathrm{U}}$ & $\frac{{ }^{230} \mathrm{Th}}{{ }^{232} \mathrm{Th}}$ & $\begin{array}{l}\frac{{ }^{230} \mathrm{Th}}{{ }^{234} \mathrm{U}} \\
\text { age (ka) }\end{array}$ & $\begin{array}{c}{ }^{14} \mathrm{C} \\
\mathrm{pMC}\end{array}$ \\
\hline $\begin{array}{l}\text { Z-1210 } \\
\text { NLfB: } \\
\text { Uh-118 }\end{array}$ & $\begin{array}{l}\text { Compact } \\
\text { travertine }\end{array}$ & $\begin{array}{r}0.14 \\
\pm 0.08\end{array}$ & $\begin{array}{r}1.25 \\
\pm 0.05\end{array}$ & $>1.59$ & $444 \pm 78$ & $\begin{aligned} & 1.30 \\
\pm & 0.1\end{aligned}$ & $\begin{array}{r}1.2 \\
\pm 0.1\end{array}$ & $\begin{array}{c}>300 \\
(>130)_{d c^{\S}}\end{array}$ & $1.5 \pm 1$ \\
\hline $\begin{array}{l}\text { Z-1210 } \\
\text { FSU: } \\
5 A, 5 B \\
54,55\end{array}$ & & $\begin{array}{c}0.26 \\
\pm 0.015\end{array}$ & $\begin{array}{r}1.32 \\
\pm 0.05\end{array}$ & & $357 \pm 60$ & -- & -- & -- & $<1.5$ \\
\hline $\begin{array}{l}\mathrm{Z}-1208 \\
\text { FSU: } \\
50+51\end{array}$ & $\begin{array}{l}\text { Porous } \\
\text { travertine }\end{array}$ & 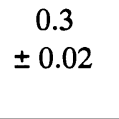 & $\begin{array}{r}1.30 \\
\pm 0.07\end{array}$ & & $379 \pm 94$ & -- & -- & -- & $2.9 \pm 1$ \\
\hline $\begin{array}{l}{ }^{* 234} \mathrm{U} /{ }^{238} \\
{ }^{\dagger} \text { Initial }{ }^{23} \\
\$ 234 \mathrm{U} /{ }^{238} \\
{ }^{8} \text { Detritus- }\end{array}$ & $\begin{array}{l}{ }^{238} \mathrm{U} \text { ratio } \\
\text { ge assumin } \\
\text { rected } \mathrm{NLf}\end{array}$ & e & . & 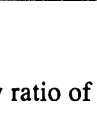 & & & & & \\
\hline
\end{tabular}

(e.g., a travertine barrier) stops growing, i.e., exchanging its ${ }^{14} \mathrm{C}$ with the environment because of perturbation of the surface flow leaving the barrier dry - a picture not too far from the basic principles of ${ }^{14} \mathrm{C}$ dating, where the death of a living organism sets the ${ }^{14} \mathrm{C}$ clock. By contrast, lake sediment in the same area, consisting of relatively pure, microscopic calcite rhombohedrons, showed a distinct ${ }^{14} \mathrm{C}$ gradient that revealed its Holocene age (Srdoč et al. 1986b). Conventional and isotopic measurements were made on samples of spring and stream water collected year-round at 40 points along the Korana River, from the karst springs to the mouth (Fig. 1). Standard physicochemical analyses and stable $\left({ }^{2} \mathrm{H},{ }^{18} \mathrm{O},{ }^{13} \mathrm{C}\right)$ and radioactive $\left({ }^{3} \mathrm{H},{ }^{14} \mathrm{C}\right)$ isotopic measurements revealed the chemistry and hydrology of the Korana River catchment area. The analysis of the data led us to the following conclusions on the formation and determination of the age of travertines (Srdoč et al. 1985b):

1. Chemical and stable isotope analyses confirmed the origin of calcareous deposits. The concentration of $\mathrm{Ca}^{2+}$ in water decreases sharply along the travertine depositing section of the Korana River, whereas $\mathrm{Mg}^{2+}$ concentration remains constant. This accords with calculated saturation indexes for $\mathrm{CaCO}_{3}$ (supersaturated) and $\mathrm{MgCO}_{3}$ (below or close to equilibrium). The $\mathrm{pH}$ of stream water in the region of intensive calcite precipitation ranges from 8.3 at the start (point YGW 711) to 8.5 (Korana Bridge) (Fig. 1).

2. The ${ }^{13} \mathrm{C}$ content of DIC and freshly deposited tufa and lake sediment, expressed as $\delta^{13} \mathrm{C}$, is close to $-12.5 \pm 0.3 \%$, again confirming that part of carbon in DIC and sediments is of biogenic origin. $\delta^{13} \mathrm{C}$ of limestone and dolomite surrounding the lakes is $\mathrm{ca} .0 .0 \pm 1 \%$, typical for marine carbonates, whereas the $\delta^{13} \mathrm{C}$ of the predominant trees (Fagus sylvatica, Abies sp.) covering a large area around the lakes ranges from -28.1 to $-30.0 \%$ (Krajcar Bronić et al. 1986). However, calculation of the initial ${ }^{14} \mathrm{C}$ activity based on the stable ${ }^{13} \mathrm{C}$ content of travertine and its sources of carbon, according to various models suggested in the literature (Tamers 1967; Mook 1976, 1980; Fontes 1983) gives erroneous results. During the isotopic exchange of carbon between ground and surface water DIC, and gaseous $\mathrm{CO}_{2}$, the ${ }^{14} \mathrm{C}$ activity of DIC always increases, whereas $\delta^{13} \mathrm{C}$ may increase in an exchange with atmospheric $\mathrm{CO}_{2}\left(\delta^{13} \mathrm{C} \sim-8 \%\right.$ o or decrease in the case of biogenic $\mathrm{CO}_{2}\left(\delta^{13} \mathrm{C} \sim-27 \%\right)$. A combination of both is very plausible in 
karst where groundwater is exposed to atmospheric $\mathrm{CO}_{2}$ in underground caverns. Thus, although $\delta^{13} \mathrm{C}$ values of DIC and calcareous deposits unmistakably prove that part of their carbon content is biogenically derived, they cannot be used to correct the ${ }^{14} \mathrm{C}$ age of travertine or groundwater in karst.

3. The ${ }^{18} \mathrm{O}$ content in travertines ranging in age from oxygen isotope Stage 11 to Recent is surprisingly constant $\left(\delta^{18} \mathrm{O}=20.0 \pm 0.8 \% o v s\right.$. Standard Mean Ocean Water (SMOW) ) indicating that environmental conditions, mainly temperature, precipitation and vegetation were similar during each formation period. This is consistent with our present knowledge of the chemistry and hydrobiology of travertine formation.

TABLE 5. Speleothems and Travertines of the Plitvice National Park, Smolcića Cave U-Series Dating

\begin{tabular}{|c|c|c|c|c|c|c|c|c|c|}
\hline $\begin{array}{l}\text { Z-no. } \\
\text { Lab. no. }\end{array}$ & $\begin{array}{l}\text { Sample } \\
\text { structure }\end{array}$ & $\begin{array}{c}\mathrm{U} \\
(\mathrm{ppm})\end{array}$ & $\frac{{ }^{234} U^{*}}{{ }^{238} U}$ & $\frac{{ }^{234} U^{\dagger}}{{ }^{238} U}$ & $\begin{array}{c}\frac{{ }^{234} \mathrm{U}^{\ddagger}}{{ }^{238} \mathrm{U}} \\
\text { age (ka) }\end{array}$ & $\frac{{ }^{230} \mathrm{Th}}{{ }^{234} \mathrm{U}}$ & $\frac{{ }^{230} \mathrm{Th}}{{ }^{232} \mathrm{Th}}$ & $\begin{array}{l}{ }^{230} \mathrm{Th} \\
{ }^{234} \mathrm{U} \\
\text { age (ka) }\end{array}$ & $\begin{array}{l}{ }^{14} \mathrm{C} \\
\mathrm{pMC}\end{array}$ \\
\hline $\begin{array}{l}\text { Z-1144 } \\
\text { NLfB: } \\
\text { Uh-116 }\end{array}$ & $\begin{array}{l}\text { Speleothems, } \\
\text { short stalac- } \\
\text { tites on cave } \\
\text { ceiling }\end{array}$ & $\begin{array}{r}0.176 \\
\pm 0.009\end{array}$ & $\begin{array}{r}1.27 \\
\pm 0.04\end{array}$ & $\begin{array}{r}1.58 \\
\pm 0.30\end{array}$ & $\begin{array}{r}417 \\
\pm 56\end{array}$ & $\begin{array}{r}0.97 \\
\pm 0.05\end{array}$ & $\begin{array}{r}3.2 \\
\pm \quad 0.2\end{array}$ & $272 \pm 90$ & $3.5 \pm 1$ \\
\hline $\begin{array}{l}\text { Z-1007 } \\
\text { FSU: } \\
48,49\end{array}$ & & $\begin{array}{r}0.51 \\
\pm 0.02\end{array}$ & $\begin{array}{r}1.32 \\
\pm 0.03\end{array}$ & -- & $\begin{array}{r}357 \\
\pm 34\end{array}$ & -- & -- & -- & $1.7 \pm 1$ \\
\hline $\begin{array}{l}\mathrm{Z}-1145 \\
\text { FSU: } \\
2 \mathrm{~A}, 2 \mathrm{~B}\end{array}$ & & $\begin{array}{r}0.55 \\
\pm 0.02\end{array}$ & $\begin{array}{r}1.28 \\
\pm 0.04\end{array}$ & -- & $\begin{array}{r}404 \\
\pm 54\end{array}$ & -- & -- & -- & $5.1 \pm 1$ \\
\hline $\begin{array}{l}\text { Z-745 } \\
\text { USGS: } \\
\text { ZAG-2 }\end{array}$ & $\begin{array}{l}\text { Very porous } \\
\text { travertine }\end{array}$ & $\begin{array}{r}0.47 \\
\pm 0.01\end{array}$ & $\begin{array}{l}1.198 \\
\pm 0.02\end{array}$ & -- & $\begin{array}{r}525 \\
\pm 36\end{array}$ & $\begin{aligned} & 1.119 \\
\pm & 0.07\end{aligned}$ & $\begin{array}{r}1.0 \\
\pm \quad 0.1\end{array}$ & $>350$ & $5.0 \pm 1$ \\
\hline $\begin{array}{l}\text { Z-741 } \\
\text { USGS: } \\
\text { ZAG-3 }\end{array}$ & & $\begin{array}{r}0.43 \\
\pm 0.01\end{array}$ & $\begin{array}{c}1.096 \\
\pm 0.02\end{array}$ & -- & $\begin{array}{r}780 \\
\pm 80\end{array}$ & $\begin{array}{r}1.02 \\
\pm 0.03\end{array}$ & $\begin{array}{r}1.4 \\
\pm \quad 0.1\end{array}$ & $>350$ & $8.0 \pm 1$ \\
\hline $\begin{array}{l}\text { Z-1213 } \\
\text { NLfB: } \\
\text { Uh-119 }\end{array}$ & $\begin{array}{l}\text { Compact } \\
\text { travertine }\end{array}$ & $\begin{array}{c}0.33 \\
\pm 0.015\end{array}$ & $\begin{array}{r}1.27 \\
\pm 0.02\end{array}$ & & $\begin{array}{r}417 \\
\pm 27\end{array}$ & -- & $\begin{array}{r}27 \\
\pm 31\end{array}$ & -- & $1.6 \pm 1$ \\
\hline $\begin{array}{l}\text { Z-1213 } \\
\text { NLfB } \\
\text { Uh-125 } \\
\text { (Uh-119 } \\
\text { redone) }\end{array}$ & & $\begin{aligned} & 0.350 \\
\pm & 0.02\end{aligned}$ & $\begin{array}{r}1.21 \\
\pm 0.02\end{array}$ & $\begin{array}{r}1.42 \\
\pm 0.40\end{array}$ & $\begin{array}{r}505 \\
\pm 35\end{array}$ & $\begin{array}{r}0.97 \\
\pm 0.02\end{array}$ & $\begin{array}{r}53 \\
\pm 21\end{array}$ & $243_{-55}^{+110}$ & \\
\hline $\begin{array}{l}Z-1213 \\
\text { FSU: } \\
3 A \& 3 B \\
54,55\end{array}$ & & $\begin{array}{r}0.44 \\
\pm 0.11\end{array}$ & $\begin{array}{r}1.30 \\
\pm 0.04\end{array}$ & & $\begin{array}{r}379 \\
\pm 51\end{array}$ & -- & -- & -- & -- \\
\hline
\end{tabular}




\section{Radiocarbon Dating of Plitvice Lakes Travertines}

${ }^{14} \mathrm{C}$ dating of travertines was introduced by Srdoc et al. (1980). Chemical processing of calcareous concretions for ${ }^{14} \mathrm{C}$ dating poses no problem, since they consist of relatively pure $\mathrm{CaCO}_{3}$, easily soluble in hydrochloric acid. Travertine samples were cleaned mechanically from intrusions and treated with diluted $\mathrm{HCl}$. The developed $\mathrm{CO}_{2}$ was trapped for subsequent purification and conversion to methane to be used as the filling gas in a proportional counter. The purification of gases, the catalytic hydrogenation of $\mathrm{CO}_{2}$, and the counting procedure were previously described (Srdoc, Breyer and Sliepčević 1971).

Several hundred travertine dates have been published, mostly from the Plitvice Lakes area and northwest Dinarides, by the Rudjer Bošković ${ }^{14} \mathrm{C}$ Laboratory group (Srdoc et al. 1977, 1980, 1982, 1987, 1992b; Obelić et al., this issue), and from several locations in Europe: Poland (Pazdur, Pazdur and Szulc 1988); Czechoslovakia (Horvatinčić et al. 1989); England (Pentecost et al. 1990), and Spain (Mas-Pla, Trilla and Vals 1992), and also from the United States (Srdoč, Chafetz and Utech 1989).

Two conspicuous periods of growth of calcareous deposits were recognized in the Plitvice Lakes region: the Holocene and a much older period, corresponding to the Würm in Europe, which was close to or beyond the lower range of the ${ }^{14} \mathrm{C}$ method (Fig. 2A). However, the older samples gave inconsistent results, sometimes yielding ages from $20-40 \mathrm{ka}$ for the same travertine outcrop. Recognizing that the ${ }^{14} \mathrm{C}$ method is sensitive to very small amounts of contamination, Srdoc et al. (1986c) suggested that this variability in the older samples was the result of exposure to atmospheric $\mathrm{CO}_{2}$, rain, and surface and groundwater, thus rendering the ${ }^{14} \mathrm{C}$ dating of travertines unreliable for samples other than those from the Holocene. The U-series dating of old travertines, containing up to $\sim 10 \%$ of modern carbon (Fig. $2 \mathrm{~A}$ ), revealed their true age.

Contamination of old travertines with modern carbon, including the man-made ${ }^{14} \mathrm{C}$ produced during thermonuclear bomb tests, renders such samples useless for ${ }^{14} \mathrm{C}$ dating; however, the impact on Recent (Holocene) travertines is less critical. Typical contamination with recent carbonate, up to several percent of modern carbon, which is easily discerned in old travertine (Fig. 2A, Tables 3-5) makes the Holocene samples appear younger from 80 up to $200 \mathrm{yr}$ (depending on the sample age) for each percent of modern carbon. This error is not very significant, taking into account other errors, such as the uncertainty in the initial activity of a travertine deposit. Previous research shows that the initial activity of calcareous deposits depends on geological setting, hydrogeology of the catchment area, vegetation and climate (Thorpe, Otlet and Sweeting 1980; Fontes 1983; Srdoc et al. 1986a; Pazdur 1988; Pazdur, Pazdur and Szulc 1988; Horvatinčić et al. 1989; Pentecost et al. 1990). Considering the importance of eliminating any ambiguity in ${ }^{14} \mathrm{C}$ dating the Plitvice Lakes travertines, an extensive study of the initial ${ }^{14} \mathrm{C}$ activity of DIC in travertine-depositing streams of the National Park area (Krajcar-Bronić et al. 1986) continued until recently (Krajcar-Bronić et al. 1992), through which a remarkably concordant and consistent set of data emerged (Srdoč et al. 1992a). Initial ${ }^{14} \mathrm{C}$ activity of travertine based on measurement of ${ }^{14} \mathrm{C}$ activity of organic material (wood, leaves) embedded in travertine and lake sediments and the adjacent calcareous deposit agreed with recent samples of travertine and the uppermost lake sediment layers, both from the prebomb test contamination era. An interesting feature, consistent with the concept of a constant isotopic exchange between the atmosphere and the hydrosphere, is a gradual downstream increase of the ${ }^{14} \mathrm{C}$ activity of DIC along the water course. Groundwater already enriched in ${ }^{14} \mathrm{C}$ above the stoichiometric value emerges at three karst springs and the surface water gains more ${ }^{14} \mathrm{C}$ activity as it flows toward lower reaches. This phenomenon is more pronounced in turbulent waters along the 
first $12 \mathrm{~km}$ of the Korana River, where numerous travertine barriers form waterfalls and cascades, than in its lower reaches. From the confluence of Crna Rijeka and Bijela Rijeka creeks near Plitvickki Ljeskovac village to the Korana Bridge $\left(12 \mathrm{~km}\right.$, Fig. 1), the present DIC ${ }^{14} \mathrm{C}$ activity increases from $71.5-91 \mathrm{pMC}$, whereas along the next $116 \mathrm{~km}$ in flat lower reaches, the increase amounts only to several percent (Srdoč et al. 1986a).

The ${ }^{14} \mathrm{C}$ ages of travertine samples in Fig. $2 \mathrm{~B}$ in the form of a histogram were calculated by taking into account the initial ${ }^{14} \mathrm{C}$ activity at the sampling location. Most of the samples were collected in the area of present-day active travertine formation shown in Figure 1, where the initial ${ }^{14} \mathrm{C}$ activity of travertine ranges from 70-83 pMC. Freshly deposited contaminated travertines shown in Figure $2 \mathrm{~A}$, with pMC above the initial ${ }^{14} \mathrm{C}$ activity, are excluded from Figure 2B. The histogram of randomly collected samples of Holocene travertine shows a declining frequency of older samples coinciding with a substantial drop in temperature in the northern hemisphere. An evident notch in the histogram ca. 2000 BP may be also related to sudden shift to cold weather (Little Ice Age). We compared the ages of recent travertine from Plitvice with the ages of Lake Prošće sediment (Srdoč et al. $1986 b$ ) as well as dates from two peat cores adjacent to Lake Prošće (Srdoč et al. 1985a). The sediment cores reached bedrock, enabling ${ }^{14} \mathrm{C}$ dating of the entire profile. Although the sediment data clearly indicate the beginning of Lake Prošće formation at $c a$. $7500 \pm 500 \mathrm{BP}$, the start of peat deposition and travertine formation is not well defined. The peat cores contained loose, partly decayed Hypnaceae; deposits of older travertine were either eroded or covered by recent debris or travertine deposits, which explains the lack of documentation for the early phase of peat and travertine formation shown in Figure 2B. Also, the peat and especially the travertine formation need not coincide with an early phase of lake formation. The growth rate of travertine progressed with the buildup of barriers, cascades and waterfalls, hence, the predominance of younger samples in the histogram (Fig. 2B). The lake formation, peat deposition and growth of recent travertine barriers coincided with global warming during the Holocene (Lamb, Lewis and Woodroffe 1966; Beget 1983; Bard et al. 1987).

\section{URANIUM-SERIES DATING OF PLITVICE TRAVERTINES}

Intensive travertine deposition during the Holocene moved downstream, leaving a few remnants of earlier and higher dams formed during the Pleistocene at several locations in the northwestern Dinarides (Plitvice Lakes, Krka and Janj Rivers). The characteristics of these travertines are: 1) their morphologic structure is similar to dry Holocene barriers or presently growing barriers; 2) most outcrops lie well above the present level of stream water; 3) their ${ }^{14} \mathrm{C}$ content is very low, between 0.0 and $1.5 \mathrm{pMC}$ for crystallized calcite and up to several percent for porous travertine due to contamination with recent calcareous deposits. However, these travertine deposits are too old to be ${ }^{14} \mathrm{C}$-dated, so that we undertook $\mathrm{U}$-series dating. The ${ }^{230} \mathrm{Th} /{ }^{234} \mathrm{U}$ method has been particularly useful in determining ages of late Quaternary carbonate formations (Ku 1976; Schwarcz 1980; Hennig, Grün and Brunnacker 1983; Mahaney 1984; Latham and Schwarcz 1992; Fontes et al. 1992). In the case of relatively pure $\mathrm{CaCO}_{3}$ deposits such as coral reefs and speleothems, results are often definitive (Atkinson and Harmon 1978; Harmon et al. 1975; Harmon, Ford and Schwarcz 1977; Harmon, Schwarcz and Ford 1977). Travertines are also suitable subjects for dating, but must be sampled and analyzed carefully, because of their porous structures and occasional impurities (Schwarcz et al. 1979; Harmon, Glazek and Nowak 1980; Hennig, Bangert and Herr 1980; Hennig, Grün and Brunnacker 1983; Blackwell and Schwarcz 1986; Kronfeld et al. 1988; Baskaran, Rajagopalan and Somayajulu 1989; Schwarcz and Latham 1989; Szabo 1990; Bischoff and Fitzpatrick 1991). In such cases, either closed-system conditions could be shown to apply, or the extent of contamination by older detritus could be demonstrated. 
A few preliminary ${ }^{230} \mathrm{Th} /{ }^{234} \mathrm{U}$ runs on the Plitvice Lakes travertines by P. O'Malley of the U.S. Geological Survey, Denver, Colorado (personal communication 1983, samples ZAG-1 through ZAG-4, Tables 2, 3 and 5) produced only partially consistent data (samples ZAG-1 (Table 3 ) and ZAG-4 (Table 2)). Measurements made at the Niedersächisches Landesamt für Bodenforschung (NLfB) Hannover, Germany by N. Horvatinčić (1985), are in general agreement with the USGS data; further measurements by Geyh and Hennig (personal communication 1990, samples Uh-663 and Uh-664, NLfB) confirmed earlier findings. Although the age of several samples of calcite crystal aggregates embedded in travertine clustered $c a .120 \mathrm{ka} \mathrm{BP}$, data on the age of the porous travertine was inconsistent and widely scattered, prompting this research.

\section{ANALYTICAL METHODS}

We followed the standard procedures for alpha spectrometric analysis of $U$ and $T$ as reviewed by Lally (1992), Ivanovich and Murray (1992) and Brook, Burney and Cowart (1990). We used ${ }^{232} \mathrm{U}$ and ${ }^{236} \mathrm{U}$ as tracers for determining of ${ }^{238} \mathrm{U}$ and ${ }^{234} \mathrm{U}$; and ${ }^{228} \mathrm{Th}$ and ${ }^{229} \mathrm{Th}$ served as tracers for determining of ${ }^{232} \mathrm{Th}$ and ${ }^{230} \mathrm{Th}$. Chemical yields averaged $50 \%$ for both $\mathrm{Th}$ and $\mathrm{U}$. We discarded samples that produced very low yields. In some cases, only the Th yields were unsatisfactory; for these we report the $\mathrm{U}$ data and calculate the ${ }^{234} \mathrm{U} /{ }^{238} \mathrm{U}$ ages.

\section{RESULTS}

\section{Water and Recent Travertines}

We analyzed three contemporary stream water samples for ${ }^{234} \mathrm{U} /{ }^{238} \mathrm{U}$ ratio, which averaged 1.88 (Table 1). The ${ }^{234} \mathrm{U} /{ }^{238} \mathrm{U}$ ratio for the four Holocene samples analyzed averaged 1.84 (Table 2). These values are identical, within uncertainty limits. This agrees with the ${ }^{14} \mathrm{C}$ data that recent travertines precipitated from contemporary surface waters.

The Holocene age of recent travertines is confirmed by our $U$-series disequilibrium studies. The most suitable samples for analysis were speleothem fragments from caves in the travertine. Three laboratories analyzed four samples (Table 2); all are low in daughter ${ }^{230} \mathrm{Th}$, with ages less than a few thousand years. The uncertainty range of the ${ }^{230} \mathrm{Th} /{ }^{234} \mathrm{U}$ dating method is much larger than ${ }^{14} \mathrm{C}$ at this age.

\section{Plitvicki Ljeskovac Samples}

A series of dry elevated barriers and outliers near Plitvicki Ljeskovac yielded ${ }^{230} \mathrm{Th} /{ }^{234} \mathrm{U}$ ages in the range 100 to $130 \mathrm{ka}$ (Table 3 ). However, not all samples were equally suitable for analysis. Two porous travertine samples gave results that were inconsistent with the compact flowstone speleothems. Six samples were concordant in $U$ concentration, $U$ isotopic ratio, and $\mathrm{Th} / \mathrm{U}$ age; thus, we assigned the age of these deposits to Isotope Stage 5 (more specifically, $5 \mathrm{e}$ or $5 \mathrm{c}$ ). The mean values, after rejecting the unreliable sample, Z-2164 (very porous travertine, ${ }^{14} \mathrm{C}$ content $7.4 \mathrm{pMC}$ ) and the ${ }^{230} \mathrm{Th} /{ }^{234} \mathrm{U}$ outlier, $\mathrm{Z}-2142$, are: $\mathrm{U}$ concentration $=0.28 \pm 0.07 \mathrm{ppm} ;{ }^{230} \mathrm{Th} /{ }^{234} \mathrm{U}$ ratio $=0.70 \pm 0.04$; mean ${ }^{230} \mathrm{Th} /{ }^{234} \mathrm{U}$ age $=117 \pm 10 \mathrm{ka}$; mean ${ }^{234} \mathrm{U} /{ }^{238} \mathrm{U}$ ratio is $1.645 \pm 0.04$; and corresponding ${ }^{234} \mathrm{U} /$ ${ }^{238} \mathrm{U}$ age is $111 \pm 24 \mathrm{ka}$.

\section{Gradina and Smolcića Cave Samples}

${ }^{230} \mathrm{Th} /{ }^{234} \mathrm{U}$ determinations were inconsistent at Gradina and Smolcića Cave; samples from the same outcrop varied widely in ${ }^{230} \mathrm{Th}$ content; however, ${ }^{234} \mathrm{U} /{ }^{238} \mathrm{U}$ ratios were all between 1.20 and 1.32 , except for 1 very porous sample (Z-741). Assuming an initial ratio of 1.88 , the ages of nine samples 
were in the range $c a .360-525 \mathrm{ka}$ (Tables 3 and 4 ). Given the very large uncertainty range of the calculations, the consistency of these results is remarkable and prompts us to propose that the deposits from these two areas are in Stage 11. The mean values of Stage 11 travertines are: $U$ concentration $=0.37 \pm 0.13 \mathrm{ppm} ;{ }^{234} \mathrm{U} /{ }^{238} \mathrm{U}$ ratio $=1.27 \pm 0.03$; and the corresponding ${ }^{234} \mathrm{U} /{ }^{238} \mathrm{U}$ age is $420 \pm 50$ ka.

\section{Discussion of Uranium-Series Dating}

Each of the techniques used in dating the Plitvice travertine deposits yielded generally consistent results, although there were a few anomalous results. Our confidence in the general conclusions of the study is based on the concordance of the three methods with respect to the three age groups (Fig. $3)$, and with field relations.

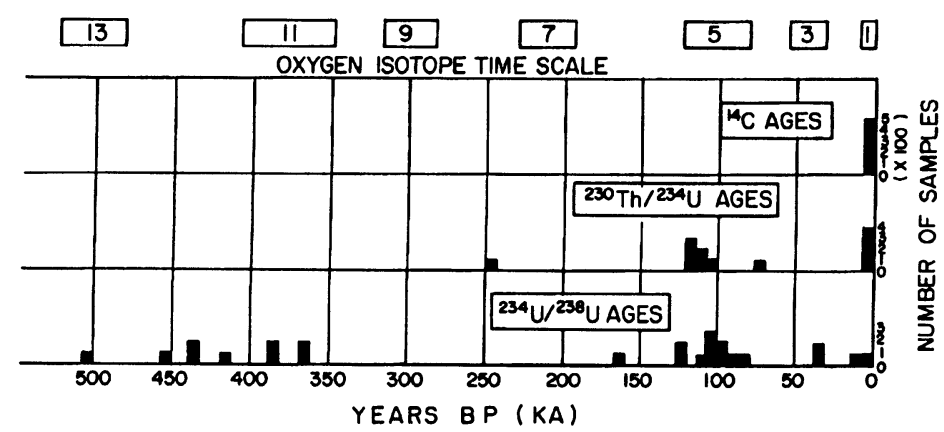

Fig. 3. Age determinations of the Plitvice Lakes carbonate samples using three dating methods. Stage 1 deposition is indicated by the ${ }^{14} \mathrm{C}$ and the two $\mathrm{U}$-series methods, Stage 5 by the two $U$-series methods and Stage 11 by the ${ }^{234} U /{ }^{238} U$ method. Stages 3, 7 and 9 appear not to be represented in the Plitvice Lakes samples.

Figure 4 shows the covariation of ${ }^{230} \mathrm{Th} /{ }^{234} \mathrm{U}$ and ${ }^{234} \mathrm{U} /{ }^{238} \mathrm{U}$ activity ratios for a dating system with no initial ${ }^{230} \mathrm{Th}$. The curved lines show the trajectory for any given initial ${ }^{234} \mathrm{U} /{ }^{238} \mathrm{U}$ ratio. All of the Plitvice samples of Stages 1 and 5 age fall on or near the curve with initial ${ }^{234} U /{ }^{238} \mathrm{U}$ activity ratio of 1.88 . The older samples with lower ${ }^{234} \mathrm{U} /{ }^{238} \mathrm{U}$ values that do not fall on the same curve show ${ }^{230} \mathrm{Th} /{ }^{234} \mathrm{U}$ values beyond the range of the method. A useful application of Figure 4 is in backtracking individual sample point trajectories to obtain their original ${ }^{234} \mathrm{U} /{ }^{238} \mathrm{U}$ activity ratios (Tables 35). The results of these calculations confirm the choice of an assumed average initial ratio of 1.88 .

The ${ }^{230} \mathrm{Th} /{ }^{234} \mathrm{U}$ ages of old travertine samples collected from the same outcrop near Plitvicki Ljeskovac (Fig. 1, area C) were extremely discordant when the material differed petrographically. Old porous travertines are usually contaminated with recent carbonates, as shown by their ${ }^{14} \mathrm{C}$ content (Tables 3-5). Although a few percent of recent carbonates does not interfere significantly with $\mathrm{U}$-series dating, the associated Th-bearing clay causes problems. A low ${ }^{230} \mathrm{Th} /{ }^{232} \mathrm{Th}$ ratio combined with a ${ }^{14} \mathrm{C}$ content $>5 \mathrm{pMC}$ indicate a high degree of contamination, rendering such samples useless for ${ }^{230} \mathrm{Th} /{ }^{234} \mathrm{U}$ dating. Typical examples, $\mathrm{Z}-2164,-741$ and -745 of very porous travertine are shown in Tables 3 and 5 . On the contrary, samples of clean crystal calcite aggregates embedded in a travertine matrix in the form of flowstones or speleothems as well as compact travertine had no significant ${ }^{14} \mathrm{C}$ activity (Tables 3-5). Paired samples Z-2144 (crystalline flowstone) and the adjacent, supposedly coeval porous travertine (Z-2146), Table 3 , illustrate the effect of contamination with recent carbonates. Sample Z-2164, Table 3, contains $8 \%$ of recent carbonate, as suggested by 


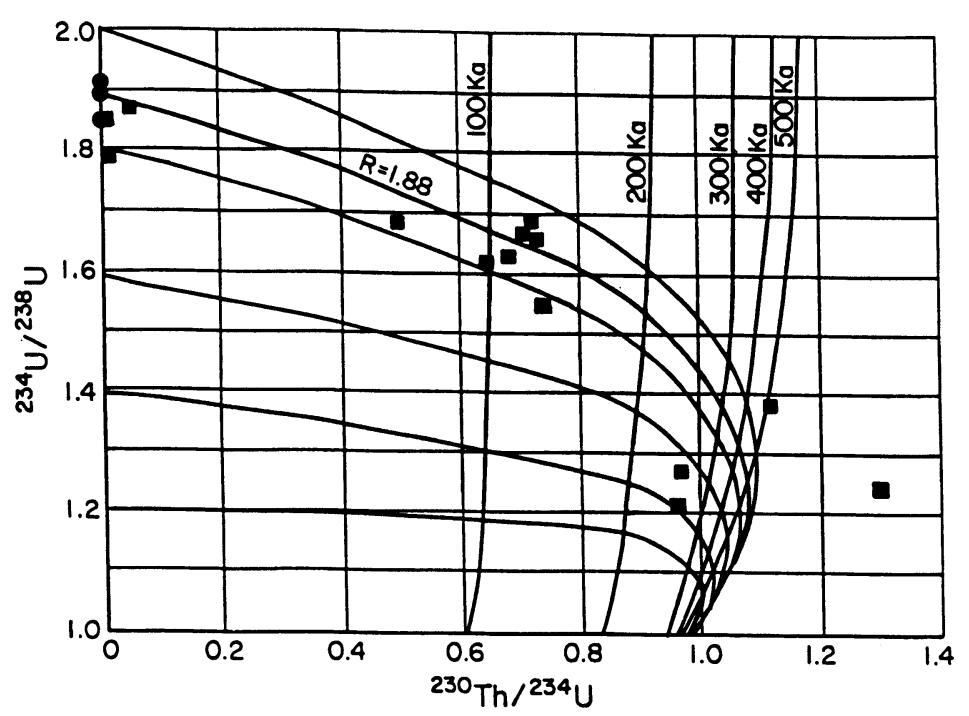

Fig. 4. Covariation decay trends of ${ }^{234} \mathrm{U} /{ }^{238} \mathrm{U}$ and ${ }^{230} \mathrm{Th} /{ }^{234} \mathrm{U}$ activity ratios in closed systems. Approximate ages of corresponding ratios are also shown. Most of the samples of this study are consistent with closed-system decay starting with ${ }^{230} \mathrm{Th} /{ }^{234} \mathrm{U}$ at 0 and ${ }^{234} \mathrm{U} /{ }^{238} \mathrm{U}$ at $c a$. 1.88 . The anomalous samples in the lower half of the plot are thought to have experienced loss or gain of thorium. $\bullet=$ modern water samples, $\mathbf{\square}=$ travertines.

its ${ }^{14} \mathrm{C}$ content, and is contaminated with detrital $\mathrm{Th}\left({ }^{230} \mathrm{Th} /{ }^{232} \mathrm{Th}<3\right)$. This sample produced inconsistent ${ }^{230} \mathrm{Th} /{ }^{234} \mathrm{U}$ and ${ }^{234} \mathrm{U} /{ }^{238} \mathrm{U}$ ages, as opposed to the adjacent crystalline sample $\mathrm{Z}-2144$ whose ${ }^{230} \mathrm{Th} /{ }^{234} \mathrm{U}$ and ${ }^{234} \mathrm{U} /{ }^{238} \mathrm{U}$ ages were both consistent with other crystalline or compact samples from the same area. ${ }^{230} \mathrm{Th} /{ }^{234} \mathrm{U}$ dating of these calcite crystal aggregates and compact travertine gave consistent and reproducible ages, clustering $c a .117 \pm 10 \mathrm{ka}$ (Table 3). The ${ }^{234} \mathrm{U} /{ }^{238} \mathrm{U}$ age obtained on the same suite of samples is $113 \pm 24 \mathrm{ka}$ (Table 3 ). Considering the inherently large error in the $\mathrm{U}$ ages, the agreement between the two $\mathrm{U}$-series methods is remarkable.

Among the generally concordant Stage 5 samples, a tendency toward an inverse covariation between $U$ concentration and ${ }^{230} \mathrm{Th} /{ }^{234} \mathrm{U}$ ratio is observed. A plausible inference is that the original $\mathrm{U}$ concentration of these samples was 0.3 to $0.4 \mu \mathrm{gg}^{-1}$, and that the samples with less have suffered U loss. Geyh and Hennig (1986, personal communication $1990,{ }^{230} \mathrm{Th} /{ }^{234} \mathrm{U}$ dates Uh-663 and Uh664 , NLfB) suggested that $\mathrm{U}$ leaching caused an excessive ${ }^{230} \mathrm{Th} /{ }^{234} \mathrm{U}$ age (e.g., Z-2164, ${ }^{230} \mathrm{Th} /$ ${ }^{234} \mathrm{U}>1$, age $>364 \mathrm{ka}$, Table 3 ). When the ${ }^{230} \mathrm{Th} /{ }^{234} \mathrm{U}$ ratio was corrected for $\mathrm{U}$ depletion (porous travertine contained $45 \%$ less $U$ than the adjacent crystal calcite), a reasonable age of close to 130 ka was obtained. The adjacent flowstone (Z-2144, Table 3) gave $127 \pm 9 \mathrm{ka}$, again consistent with a Stage 5 formation period.

${ }^{234} \mathrm{U} /{ }^{238} \mathrm{U}$ dating depends on the degree of initial disequilibrium as well as stability. The relatively high ratio at Plitvice is fortunate in this respect, although such values have been reported in other carbonate groundwaters. Osmond and Cowart $(1976,1992)$, Osmond and Ivanovich (1992) and others have discussed the question of how such extreme isotopic fractionation occurs in natural waters. The reliability of ${ }^{234} \mathrm{U} /{ }^{238} \mathrm{U}$ dating depends primarily on the assumption of known initial ratio. The consistency of the ratio used, 1.88 , with modern water samples, Holocene travertines and Stage 5 travertines, in this respect (Fig. 4), is the principal basis for our confidence in the dating of 
the Stage 11 samples. This same approach has been used by others in the study of speleothems: confidence in the long-term stability of the ${ }^{234} \mathrm{U} /{ }^{238} \mathrm{U}$ ratio in some carbonate terrains seems justified (Thompson, Ford and Schwarcz 1975; Thompson et al. 1975; Harmon, Ford and Schwarz 1977; Gascoyne and Nelson 1983); in other cases, variability is suspected (Thompson et al. 1977; Harmon et al. 1978; Hennig, Grün and Brunnacker 1983). One would expect to find less secular variability in waters issuing from major springs, as at Plitvice, than from cave seeps. At Plitvice, carbonate deposition appears to have occurred only during warm climate stages, so that $U$ isotopic responses to climate change would be minimized.

Because both parent and daughter have identical chemical behavior in ${ }^{234} \mathrm{U} /{ }^{238} \mathrm{U}$ dating, the possibilities for natural and laboratory fractionation, as with $\mathrm{Th} / \mathrm{U}$ dating, are eliminated. Sample characteristics, such as density and porosity, should have less effect on the result. However, chemical exchange of young $U$ with old mineral systems, or physical mixing of old and young travertines, could produce anomalous ages.

That Stage 11 travertines, but not 7 and 9 , should be prominently represented at Plitvice may have special significance. Lloyd Burckle (ms.) of Lamont-Doherty Earth Observatory at Palisades, New York, has exhaustively reviewed the Quaternary climate record and believes that Stage 11 temperatures were probably warmer than any time before or since. Burckle points to supporting evidence in both the marine (Ruddiman et al. 1989; Oppo, Fairbanks and Gordon 1990) and continental (Rousseau, Puissegur and Lecolle 1992) spheres. Burckle also notes that much circumstantial evidence exists for a pre-Stage 5 warming episode which, for lack of a suitable dating technique, cannot definitely be assigned to Stage 11 . Other investigators have assigned ${ }^{230} \mathrm{Th} /{ }^{234} \mathrm{U}$ travertine dates to Stage 7 (e.g., Harmon, Glazek and Nowak 1980; Blackwell and Schwarcz 1986). However, as Hennig et al. (1983) indicated, the pre-Stage $5{ }^{230} \mathrm{Th} /{ }^{234} \mathrm{U}$ carbonate dating is quite problematic and the accumulation of published results reveals no consistent pattern.

\section{Conclusions}

${ }^{14} \mathrm{C}$ and $\mathrm{U}$-series techniques used in dating the Plitvice Lakes travertine deposits yielded results which were generally concordant, although there were, in each case, a few anomalies. Our confidence in the general conclusions of the study is based on the agreement of data obtained by the different methods for the three age groups (Stages 1, 5 and 11, Fig. 3), and with field relations.

${ }^{14} \mathrm{C}$ dating of Holocene travertine produced reliable ages concordant with sedimentological and climate studies, pollen analysis, and ${ }^{14} \mathrm{C}$ ages of detrital organic material (fragments of wood, leaves) embedded in travertine matrix, as well as of peat cores from peat bogs adjacent to the Lakes.

The reproducibility of ${ }^{230} \mathrm{Th} /{ }^{234} \mathrm{U}$ ages obtained on pure calcite crystal aggregates embedded in travertine assured us that the agreement between the mean age of clean calcite samples $(120 \pm 10$ ka) and the warm, humid Stage 5 is not fortuitous. The concordant results of independent measurements at three laboratories further confirmed the reliability of the ${ }^{230} \mathrm{Th} /{ }^{234} \mathrm{U}$ technique for dating clean calcite samples within the range of the method. Porous travertine samples are not suitable for $\mathrm{U}$-series dating. The reliability of $\mathrm{U}$-series methods of dating travertine samples diminishes with increasing porosity indicated by high ${ }^{14} \mathrm{C}$ content of old samples (pMC $>5$ ) and Th contamination $\left({ }^{230} \mathrm{Th} /{ }^{232} \mathrm{Th}<3-5\right)$. The dense crystalline speleothems yield the most consistent results, whereas the compact travertine is susceptible to contamination and requires testing for its purity.

The agreement between ${ }^{230} \mathrm{Th} /{ }^{234} \mathrm{U}$ ages and ${ }^{14} \mathrm{C}$ results on the Holocene samples gave assurance that the Stage $5^{230} \mathrm{Th} /{ }^{234} \mathrm{U}$ ages are correct. By analogy, the agreement between ${ }^{234} \mathrm{U} /{ }^{238} \mathrm{U}$ ages and 
${ }^{230} \mathrm{Th} /{ }^{234} \mathrm{U}$ ages on Holocene and Stage 5 samples verified that the Stage $11^{234} \mathrm{U} /{ }^{238} \mathrm{U}$ ages are correct. The ${ }^{14} \mathrm{C}$ and $\mathrm{U}$-series ages indicate that there have been three short periods of travertine formation at the Plitvice Lakes, corresponding to climate oxygen isotopic Stages 1 (modern), 5 (last interglacial stage), and 11 (an earlier interglacial stage).

\section{ACKNOWLEDGMENTS}

The authors wish to express their gratitude to the following colleagues who supplied U-series analysis data obtained at their laboratories: B. J. Szabo and P. O'Malley of the U.S. Geological Survey, Denver, Colorado, and M. A. Geyh and G. Hennig of Niedersächisches Landesamt für Bodenforschung, Hannover, Germany. Thanks are also due I. Krajcar Bronić for her help during preparation of the manuscript and the Rudjer Boškovic ${ }^{14} \mathrm{C}$ Laboratory staff for the ${ }^{14} \mathrm{C}$ analyses of travertine samples. We gratefully acknowledge our reviewers for their valuable comments and suggestions, and persistence to upgrade the manuscript.

\section{REFERENCES}

Atkinson, T. C. and Harmon, R. S. 1978 Paleolithic and geomorphic implications of ${ }^{230} \mathrm{Th} /{ }^{234} \mathrm{U}$ dates on speleothems from Britain. Nature 272: 24-26.

Bard, E., Arnold, M., Maurice, P., Dupart, J. and Duplessy, J.-C. 1987 Retreat velocity of the North Atlantic polar front during the last deglaciation determined by ${ }^{14} \mathrm{C}$ accelerator mass spectrometry. Nature 328: 791794.

Baskaran, M., Rajagopalan, G. and Somayajulu, B. L. K. $1989{ }^{230} \mathrm{Th} /{ }^{234} \mathrm{U}$ and ${ }^{14} \mathrm{C}$ dating of the Quaternary carbonate deposits of Saurashtra, India. Chemical Geology-Isotope Geoscience 79: 65-82.

Beget, E. J. 1983 Radiocarbon-dated evidence of worldwide early Holocene climate change. Geology 11: 389-393.

Bischoff, J. L. and Fitzpatrick, J. A. 1991 U-series dating of impure carbonates: An isochron technique using total-sample dissolution. Geochimica et Cosmochimica Acta 55: 543-554.

Blackwell, B. and Schwarcz, H. P. 1986 U-series analyses of the lower travertine at Ehringsdorf, DDR. Quaternary Research 25: 215-222.

Brook, G. A., Burney, D. A. and Cowart, J. B. 1990 Desert paleoenvironmental data from cave speleothems with examples from the Chihuahuan, Somali-Chabi and Kalahari deserts. Paleogeography, Paleoclimatology, Paleoecology 76: 311-329.

Burckle, L. H. (ms.) Late Quaternary interglacial stages warmer than present (unpublished data).

Burr, G. S., Edwards, R. L., Donahue, D. J., Druffel, E. R. M. and Taylor, F. W. 1992 Mass spectrometric ${ }^{14} \mathrm{C}$ and $\mathrm{U} / \mathrm{Th}$ measurements in coral. In Long, A. and Kra, R. S., eds., Proceedings of the 14th International ${ }^{14} \mathrm{C}$ Conference. Radiocarbon 34(3): 611-618.

Chafetz, H., and Folk, R. L. 1984 Travertines - depositional morphology and the bacterially constructed constituents. Journal of Sedimentary Petrology 54: 289-316.
Chafetz, S. H., Srdoc, D. and Horvatinčic, N. 1990 Pervasive sparmicritization of waterfall and barrier travertines, Plitvice National Park, Croatia, Yugoslavia. 13th International Sedimentological Congress, Nottingham, England, 82-83. Abstract.

Chafetz, S. H., Srdoc, D. and Horvatinčic, N. 1994 Early diagenesis of Plitvice Lakes waterfall and barrier travertine deposits. Géographie Physique et Quaternaire, in press.

Fontes, J.-C. 1983 Dating of groundwater. In Guidebook on Nuclear Techniques in Hydrology. Vienna, IAEA, Technical Report Series 91: 285-317.

Fontes, J.-C. Andrews, J. N., Causse, C. and Gibert, E. 1992 A comparison of radiocarbon and $U / T h$ ages on continental carbonates. In Long, A. and $\mathrm{Kra}, \mathrm{R}$. S., eds., Proceedings of the 14 th International ${ }^{14} \mathrm{C}$ Conference. Radiocarbon 34(3): 602-610.

Gascoyne, M. and Nelson, D. E. 1983 Growth mechanisms of recent speleothems from Castleguard Cave, Columbia icefields, Alberta, Canada, inferred from a comparison of uranium-series and ${ }^{14} \mathrm{C}$ age data. Arctic and Alpine Research 15: 537-542.

Geyh, M. A. and Hennig, G. J. 1986 Multiple dating of a long flowstone profile. In Stuiver, M. and Kra, R. S., eds., Proceedings of the 12 th International ${ }^{14} \mathrm{C}$ Conference. Radiocarbon 28(2A): 503-509.

Golubic, S. 1973 The relationship between blue-green algae and carbonate deposits. In Carr, N. G. and Whitton, B. A., eds., The Biology of Blue-Green Algae. Blackwell, Oxford: 434-472.

Harmon, R. S., Ford, D. C. and Schwarcz, H. P. 1977 Interglacial chronology of the Rock and Mackenzie Mountains based upon ${ }^{230} \mathrm{Th} /{ }^{234} \mathrm{U}$ dating of calcite speleothems. Canadian Journal of Earth Sciences 14: 2543-2552.

Harmon, R. S., Glazek, J. and Nowak, K. $1980{ }^{230} \mathrm{Th} /$ ${ }^{234} \mathrm{U}$ dating of travertine from the Bilzingsleben archaeological site. Nature 284: 132-135. 
Harmon, R. S., Schwarcz, H. P. and Ford, D. C. 1977 Stable isotope geochemistry of speleothem and cave waters from the Flint Ridge-Mammoth Cave system, Kentucky: Implications for terrestrial climate change during the period 230,000 to 100,000 years B.P. Journal of Geology 86: 373-384.

Harmon, R. S., Schwarcz, H. P., Thompson, P. and Ford, D. C. 1978 Critical comment on "Uranium series dating of stalagmites from Blanchard Springs Cavern, Arkansas, U.S.A.". Geochimica et Cosmochimica Acta 42: 433-439.

Harmon, R. S., Thompson, P., Schwarcz, H. P. and Ford, D. C. 1975 Uranium-series dating of speleothems. National Speleological Society Bulletin 37: 21-33.

Hennig, G. J., Bangert, U. and Herr, W. 1980 Dating of speleothem by disequilibria in the U-decay series. British Museum Occasional Paper 21: 73.

Hennig, G. J., Grün, R. and Brunnacker, K. 1983 Speleothems, travertines, and paleoclimates. Quaternary Research 20: 1-29.

Horvatincić, N. (ms.) 1985 Radiocarbon Age Measurements of Tufa Deposits from the Plitvice Lakes Area (in Croatian with English summary). Ph.D. Dissertation, Zagreb University, Croatia.

Horvatincič, N., Srdoč, D., Šilar, J. and Tvrdikova, H. 1989 Comparison of the ${ }^{14} \mathrm{C}$ activity of groundwater and recent tufa from karst areas in Yugoslavia and Czechoslovakia. In Long, A., Kra, R. S. and Srdox, D., eds., Proceedings of the 13 th International ${ }^{14} \mathrm{C}$ Conference. Radiocarbon 31(3): 884-892.

Ivanovich, M. and Murray, A. 1992 Spectrometric methods. In Ivanovich, M. and Harmon, R., eds., Uranium Series Disequilibrium: Applications to Environmental Problems, Second edition. Oxford, Oxford University Press: 127-173.

Krajcar Bronić, I., Horvatinčić, N., Srdoc, D. and Obelić, B. 1992 Experimental determination of the ${ }^{14} \mathrm{C}$ initial activity of calcareous deposits. In Long, A. and $\mathrm{Kra}$, R. S., eds., Proceedings of the 14 th International ${ }^{14} \mathrm{C}$ Conference. Radiocarbon 34(3): 593-601.

1986 On the initial ${ }^{14} \mathrm{C}$ activity of karst aquifers with short mean residence time. In Stuiver, M. and Kra, R. S., eds., Proceedings of the 12th International ${ }^{14} \mathrm{C}$ Conference. Radiocarbon 28(2A): 436-440.

Kronfeld, J., Vogel, J. C., Rosenthal, E. and Weinstein-Evron, M. 1988 Age and climatic implications of the Bet Shean Travertines. Quaternary Research 30: 298-303.

$\mathrm{Ku}, \mathrm{T}$. L. 1976 The uranium-series methods of age determination. Annual Review of Earth and Planetary Sciences 4: 347-379.

Lally, A. E. 1992 Chemical procedures. In Ivanovich, M. and Harmon, R., eds., Uranium Series Disequilibrium: Applications to Environmental Problems, Second edition. Oxford, Oxford University Press: 79-106.

Lamb, H. H., Lewis, R. and Woodroffe, A. 1966 Atmospheric circulation and the main climatic variables. Proceedings of the International Symposium on World
Climate from 8000 to 0 B.C. London, Royal Meteorological Society: $174 \mathrm{p}$.

Latham, A. G. and Schwarcz, H. P. 1992 Carbonate and sulphate precipitates. In Ivanovich, M. and Harmon, R., eds., Uranium Series Disequilibrium: Applications to Environmental Problems, Second edition. Oxford, Oxford University Press: 423-459.

Mahaney, W. C., ed. 1984 Quaternary Dating Methods. Amsterdam, Elsevier Scientific Publishing Co.

Marčenko, E., Srdoč, D., Golubić, S., Pezdix, J. and Head, M. J. 1989 Carbon uptake in aquatic plants deduced from their natural ${ }^{13} \mathrm{C}$ and ${ }^{14} \mathrm{C}$ content. In Long, A., Kra, R. S. and Srdoč, D., eds., Proceedings of the 13th International ${ }^{14} \mathrm{C}$ Conference. Radiocarbon 31(3): 785-794.

Mas-Pla, J., Trilla, J. and Valls, M. L. 1992 Radiocarbon dating of travertines precipitated from freshwater. In Long, A. and Kra, R. S., eds., Proceedings of the 14th International ${ }^{14} \mathrm{C}$ Conference. Radiocarbon $34(3)$ : 677-685.

Mook, W. G. 1976 The dissolution-exchange model for dating groundwater with ${ }^{14} \mathrm{C}$. Interpretation of environmental isotope and hydrochemical data. In Groundwater Hydrology. Vienna, IAEA: 213-225.

1980 Carbon-14 in hydrology studies. In Fritz, P. and Fontes, J. C., eds., Handbook of Environmental Isotope Geochemistry 1: 49-74. Amsterdam, Elsevier Scientific Publishing Co.

Obelič, B., Horvatinčić, N., Srdoč, D., Krajcar Bronić, I. and Sliep̌̌evic, A. 1994 Rudjer Bošković Institute Radiocarbon Measurements XIII. Radiocarbon, this issue.

Oppo, D. W., Fairbanks, R. G. and Gordon, A. L. 1990 Late Pleistocene Southern Ocean ${ }^{13} \mathrm{C}$ variability. $\mathrm{Pa}$ leoceanography 5: 43-54.

Osmond, J. K. and Cowart, J. B. 1976 The theory and uses of natural uranium isotopic variations in hydrology. Atomic Energy Review 14: 621-679.

1992 Ground water. In Ivanovich, M. and Harmon, R., eds. Uranium Series Disequilibrium: Applications to Environmental Problems, Second edition. Oxford, Oxford University Press: 290-323.

Osmond, J. K. and Ivanovich, M. 1992 Uranium-series mobilization and surface hydrology. In Ivanovich, M. and Harmon, R., eds., Uranium Series Disequilibrium: Applications to Environmental Problems, Second edition. Oxford, Oxford University Press: 259-289.

Pazdur, A. 1988 The relation between carbon isotope composition and apparent age of freshwater tufaceous sediments. Radiocarbon 30(1): 7-18.

Pazdur, A., Pazdur, M. F. and Szulc, J. 1988 Radiocarbon dating of Holocene calcareous tufa in southern Poland. Radiocarbon 30(2): 133-151.

Pentecost, A., Thorpe, P. M., Harkness, D. D. and Lord, T. C. 1990 Some radiocarbon dates for tufa of the Craven district of Yorkshire. Radiocarbon 32(1): 93-97.

Polšak, A. 1979a Upper Cretaceous beds of the Northwestern part of outer Dinarides; Lika, Croatian littoral and Istria. In Proceedings of the 16th European Mi- 
cropaleontological Colloquium. Slovenian Academy of Sciences, Ljubljana, Slovenia: 101-106.

$1979 \mathrm{~b}$ The Plitvice Lakes. In Proceedings of the 16th European Micropaleontological Colloquium, Slovenian Academy of Sciences. Slovenian Academy of Sciences, Ljubljana, Slovenia: 157-162.

Rousseau, D.-D., Puissegur, J.-J. and Lecolle, F. 1992 West-European mollusc assemblages of isotopic stage 11 (middle Pleistocene): Climatic implications. Palaeogeography, Palaeoclimatology, Palaeoecology 92: 15-29.

Ruddiman, W. F., Raymo, M. E., Martinson, D. G., Clement, B. M. and Backman, J. 1989 Pleistocene evolution of northern hemisphere climate. Paleoceanography 4: 353-412.

Schwarcz, H. P. 1980 Absolute age determination of archaeological sites by uranium series dating of travertine. Archaeometry 22(1): 3-24.

Schwarcz, H. P., Blackwell, B., Goldberg, P. and Marks, A. E. 1979 Uranium series dating of travertine from archaeological sites, Nahal Zin, Israel. Nature 277: 558-560.

Schwarcz, H. P. and Latham, A. G. 1989 Uranium series dating of contaminated calcite using leachates alone. Chemical Geology (Isotope Geoscience Section) 80: 35-43.

Srdox, D. 1986 The response of hydrological systems to the variations of the ${ }^{14} \mathrm{C}$ activity of the atmosphere. In Povinec, P. ed., Proceedings of the 3rd International Conference on Low Radioactivity Measurement and Application, Bratislava. Nuclear Instruments and Methods in Physic Research B17: 545-549.

Srdox, D., Breyer, B. and Sliep̌evic, A. 1971 Rudjer Bošković Institute radiocarbon measurements I. Radiocarbon 13(1): 135-140.

Srdoc, D., Chafetz, H. and Utech, N. 1989 Radiocarbon dating of travertine deposits, Arbuckle Mts., Oklahoma. In Long, A., Kra, R. S. and Srdoc, D., eds., Proceedings of the 13 th International ${ }^{14} \mathrm{C}$ Conference. Radiocarbon 31(3): 619-626.

Srdoc, D., Krajcar Bronić, I., Horvatinčic, N. and Obelic, B. 1986a The increase of ${ }^{14} \mathrm{C}$ activity of dissolved inorganic carbon along the river course. In Stuiver, M. and Kra, R. S., eds., Proceedings of the 12th International ${ }^{14} \mathrm{C}$ Conference. Radiocarbon 28(2A): 515521.

Srdoð, D., Obelić, B., Horvatinčic, N. Culiberg M., Šercelj A. and Sliepčević, A. 1985a Radiocarbon dating and pollen analyses of two peat bogs in the Plitvice National Park. Acta Botanica Croatica 44: 41-46.

Srdoc, D., Obelic, B., Horvatinčč, N. and Sliepčević, A., 1980 Radiocarbon dating of calcareous tufa; How reliable data can we expect? In Stuiver, M. and Kra, R. S., eds., Proceedings of the 10 th International ${ }^{14} \mathrm{C}$ Conference. Radiocarbon 22(3): 858-862.

Srdoc, D., Obelic, B., Horvatinčić, N., Krajcar Bronić, I., Marčenko, E., Merkt, S., Wong, H. K. and Sliepčevic, A. 1986b Radiocarbon dating of lake sediments from two karstic lakes in Yugoslavia. In Stuiver, M. and Kra, R. S., eds., Proceedings of the 12th International ${ }^{14} \mathrm{C}$ Conference. Radiocarbon 28(2A): 495-502.

Srdoc, D., Obelic, B., Sliepěević, A., Krajcar Bronić, I. and Horvatinčć, N. 1987 Rudjer Bošković Institute radiocarbon measurements X. Radiocarbon 29(1): 135-147.

Srdoc, D., Sliepčević, A., Obelić, B., and Horvatinčić, N. 1977 Rudjer Bošković Institute radiocarbon measurements IV. Radiocarbon 19(3): 465-475.

Srdoč, D., Horvatinčic, N., Ahel, M., Giger, W., Schaffner, C., Krajcar Bronic, I., Petricioli, D., Pezdic, J., Marčenko, E. and Plenković, A. 1992a Anthropogenic influence on the ${ }^{14} \mathrm{C}$ activity of recent lake sediment. A case study. In Long, A. and Kra, R. S., eds., Proceedings of the 14 th International ${ }^{14} \mathrm{C}$ Conference. Radiocarbon 34(3): 585-592.

Srdoč, D., Horvatinčić, N., Krajcar Bronić, I. Obelić, B. and Sliepčević, A. 1992b Rudjer Bošković Institute radiocarbon measurements XII. Radiocarbon 34(1): 155-175.

Srdoč, D., Horvatinčic, N., Obelić, B. and Sliepčević, A. 1982 Rudjer Bošković Institute radiocarbon measurements VII. Radiocarbon 24(3): 352-371.

Srdoc, D., Horvatinčić, N., Obelić, B., Krajcar, I. and Sliepcevic, A. 1985b Calcite deposition processes in karstwaters with special emphasis on the Plitvice Lakes, Yugoslavia. Carsus Iugoslaviae 11/4-6: 101204 (in Croatian, with extended English abstract).

Srdox, D., Horvatinđ̌ic, N., Obelić, B., Krajcar-Bronic, I. and O'Malley, P. 1986c The effects of contamination of calcareous sediments on their radiocarbon age. In Stuiver, M. and Kra, R. S., eds., Proceedings of the 12th International ${ }^{14} \mathrm{C}$ Conference. Radiocarbon 28 (2A): 510-514.

Srdoč, D., Horvatincić, N., Obelić, B., Krajcar Bronić, I. and Sliepčević, A. 1987 Rudjer Boškovic Institute radiocarbon measurements IX. Radiocarbon 29(1): 115-147.

Szabo, B. J. 1990 Ages of travertine deposits in Eastern Grand Canyon National Park, Arizona. Quaternary Research 34: 24-32.

Tamers, M. A. 1967 Surface-water infiltration and groundwater movement in arid zones of Venezuela. In Isotope Hydrology. Vienna, IAEA: 241-257.

Thompson, G., Lumsden, N., Walker, R. and Carter, J. 1975 Uranium series dating of stalagmites from Blanchard Springs Cavern, U.S.A. Geochimica et Cosmochimica Acta 39: 1211-1218.

Thompson, P., Ford, D. C. and Schwarcz, H. P. 1975 ${ }^{234} \mathrm{U} /{ }^{238} \mathrm{U}$ ratios in limestone cave seepage waters and speleothems from West Virginia. Geochimica et Cosmochimica Acta 39: 661-669.

Thorpe, P. M., Otlet, R. L. and Sweeting, M. M. 1980 Hydrological implications from ${ }^{14} \mathrm{C}$ profiling of UK tufa. In Stuiver, M. and Kra, R. S., eds., Proceedings of the 10th International ${ }^{14} \mathrm{C}$ Conference. Radiocarbon 22(3): 897-908. 